\title{
MONITORING FUNCTION OF DPRD TOWARD IMPLEMENTATION OF THE REGIONAL BUDGET REGULATION BULUNGAN REGENCY 2015
}

\section{Iskandar ${ }^{1}$, Jimmy Nasroen ${ }^{2}$}

\author{
${ }^{1,2}$ Lecturer at Universitas Kaltara \\ ${ }^{1}$ Email: padosunikalsospol@gmail.com \\ ${ }^{2}$ Email: jimmynasroen@gmail.com
}

DOI: https://doi.org/10.18196/jgpp.5190

Article Info

Article history:

Received 14 Jan 2018

Revised 1 Feb 2018

Accepted 20 Feb 2018
Keyword: Monitoring Function, Regional Budget Regulation Implementation

\section{ABSTRACT}

Based on the problem of research, the aim of this research are to determine and to asses deeply about monitoring function of Regional House of Representatives (DPRD) toward implementation of regional budget (APBD) regulation in Bulungan Regency in the year of 2015. The type of this research is descriptive-qualitative research which aimed to give a picture or painting of the situation systematically, factual, and accurate related with the research object then the result will be continued with detail explanation. Informan on this research are people who have competency to give information or data which are accurate and accountable related to the problem of research. The informan here are the whole members of Regional House of Representatives (DPRD) Bulungan Regency, that had been chosen randomly without consider their strata. The conclusion of this research said that the monitoring function toward regional budget (APBD) regulation in Bulungan regency had implemented but still not optimal. It is prove that there is a unsynchronized between planning with the result of local development planning consensus (Musrenbang) that was established and become the development priority. It is showed that political commitment of Regional House of Representatives (DPRD) toward budget monitoring still not yet optimal. The author give some suggestions to enforce the role of Regional House of Representatives (DPRD) in the field of monitoring. Regional House of Representatives (DPRD) should increase capability and knowledge, conceptional and operational institutionally about monitoring function which tend to policy, Regional House of Representatives (DPRD) should hire experts which have capability in their fields, that do the assesment for give input.

\section{ABSTRAK}

Berdasarkan rumusan masalah maka tujuan dari penelitian yang akan dilakukan yaitu untuk mengetahui dan mengkaji secara lebih mendalam mengenai fungsi pengawasan DPRD terhadap pelaksanaan peraturan daerah tentang Anggaran Pendapatan dan Belanja Daerah Kabupaten Bulungan tahun 
2015. Jenis Penelitian ini adalah penelitian deskriptif kualitatif yaitu suatu tipe penelitian yang bertujuan untuk memberikan gambaran atau lukisan situasi secara sistematis, faktual, dan akurat mengenai objek yang diteliti yaitu hasil deskriptif dilanjutkan dengan penjelasan secara rinci dan mendetail. Informan dalam penelitian ini adalah orang - orang yang berkompeten memberikan informasi atau data yang akurat dan akuntabel berkaitan dengan permasalahan yang diteliti. Informan dalam penelitian ini adalah seluruh anggota DPRD Kabupaten Bulungan, yang dipilih secara acak tanpa memperhatikan strata yang ada. Berdasarkan hasil penelitian maupun dalam bahasan fokus masalah maka dapat ditarik kesimpulan sebagai berikut ,Fungsi pengawasan terhadap pelaksanaan perda tentang Anggaran Pendapatan dan Belanja Daerah di Kabupaten Bulungan dalam melaksanakan fungsi pengawasan terhadap pelaksanaan APBD tahun 2015 telah berjalan, namun belum optimal ini dibuktikan bahwa masih ditemui ketidaksinkronisasi antara perencanaan dengan hasil musrenbang yang telah ditetapkan dan menjadi prioritas pemabangunan hal ini menunjukan belum optimalnya komitmen politik DPRD terhadap pengawasan anggaran. Saran-saran yang penulis berikan dalam rangka penguatan peran DPRD yaitu sebaiknya DPRD secara institusional meningkatkan kemampuan dan pengetahuan, konsepsional dan operasional tentang pengawasan Anggaran dan Pendapatan Belanja Daerah. Untuk memudahkan fungsi pengawasan yang bersifat kebijakan sebaiknya DPRD memakai tenaga ahli yang memiliki kemampuan di masing-masing bidang yang bertugas melakukan pengkajian guna memberikan saran dan masukan

\section{INTRODUCTION}

Role enforcement of legislative assembly in this reformation era is a must that could not be refuted about its existence. As we know, the function and role of Regional House of Representatives (DPRD) are listed on clause 149 Act Number 23 Year of 2014, which set that Regional House of Representatives (DPRD) have some functions: a. Forming regional regulation of regency/city; b. Budget; and c.Monitoring. As a provision in the Act that become internal need about how Regional House of Representatives (DPRD) could construct a work mechanism which capable 
to optimalize the performance within task attainment and function of Regional House of Representatives (DPRD). Cultivate awareness of Regional House of Representatives (DPRD) about its function is a must need and urgent to be implemented.

Because the common people have a lot of hope and believe that Regional House of Representatives (DPRD) capable to do its functions in parliament by positioning itself as public representatives which chosen based on reliance, so it is needed more real role and the advantage could be perceived by the people. As the direct democracy revolution, then representative democracy was born, which realized with the forming of institution as a place to vocalize various interest aspiration and people will globally. In common, this institution known as parliament or parliamentary or people representative which chosen by the people directly, with represent their constituency/people.

Now, there is a heavy encumbrance that stacked to Local Government and Regional House of Representatives (DPRD). This encumbrance is a effort to accelerate development growth, welfare, absorp people aspiration, and running the trust that stacked to them which selected through direct democracy. Regional House of Representatives (DPRD) is a part of government element which widely called with "partner" of executive on running the government. Regional House of Representatives (DPRD) as a vehicle to implement democracy based on Pancasila. So that, in the way to execute task and function, Regional House of Representatives (DPRD) hold on the principles of regional autonomy within framework corridor of NKRI. 
Main function of Regional House of Representatives (DPRD) as people representative, as we know have three function i.e budget function, legislation function, and monitoring function. One of them, is implement monitoring toward regional budget (APBD) management. Thus, in this research would be focused on assesment about one Regional House of Representatives (DPRD) main functions i.e monitoring function. Monitoring function of Regional House of Representatives (DPRD) toward local government policy is a deviation and violation potential area in the budget utilization that called with regional budget (APBD).

Act number 23 year of 2014 about local government explain that Regional House of Representatives (DPRD) position is very strategic and very decisive on implementation of regional autonomy within local government management. Regional House of Representatives (DPRD) is a regional people representatives institution and domicilied as element of local government management which have legislation function, budget function, and monitoring function.

The form of monitoring which is conducted by Regional House of Representatives (DPRD) is a political monitoring, i.e monitoring which conducted by legislative institution toward executive institution (Head of region along with the staff) that more tend to strategic policy and not include in tehnical monitoring or administrative, because Regional House of Representatives (DPRD) is a political institution, like budget utilization which was allocate, misused for things that harm for the people and the state.

Function, task, authority, and rights of Regional House of Representatives (DPRD), be expected Regional House of Representatives 
(DPRD) could present its role optimally carry on control function toward implementation of regional regulation. The goal is realization of local government which is efficient, clean, commanding, and free from any kind of practice that indicated corruption, colution, and nepotism (KKN).

Task and authority of Regional House of Representatives (DPRD) execute monitoring toward implementation of regional regulation contained in clause 153 Act Number 23 year of 2014 said: the task and authority of Regional House of Representatives (DPRD) toward implementation of regional regulation and the other regulations, regulation of regional head, regional budget (APBD), local government policy on the implementation of regional development and international collaboration in region.

Monitoring function of Regional House of Representatives (DPRD) have tight relation with legislation function, because basically the object of monitoring is related with the implementation of the regional regulation itself and public policy implementation which contained in the regional regulation. Increasing of legislative role (DPRD) actually aimed to creation of "check and balance", evidently generated situation that not expected often sounded refusal statement the member of Regional House of Representatives (DPRD) toward accountability report of regional head long before the report be delivered, be discussed, and be clarified accompanied threat of dropped of disbelieve motion.

Because in essence, Regional Budget (APBD) is an embodiment of people's mandate toward government through Regional House of Representatives (DPRD) on increase people 
welfare. Regional budget (APBD) also called as annual finance planning of local government which is approved by Regional House of Representatives (DPRD) and set with regional regulatio (Perda). Consequently, local government needs to pay attention that regional budget (APBD) is an embodiment of people's mandate which used for increase people's welfare, then in order to avoid deviation and violation in the implementation of regional budget (APBD), strong monitoring from Regional House of Representatives (DPRD) is required.

Monitoring toward regional budget (APBD) will be more effective if the whole member of Regional House of Representatives (DPRD) could positioning/put theirself as inspector suitable with one of Regional House of Representatives (DPRD)'s function i.e budgeting (budget/APBD) monitoring function. It will be more effective if people take part to help and give information support against deviation of regional budget (APBD) in the sphere.

But, in fact it is very different, nowadays misused of regional budget (APBD) often happened, which did by the member of Regional House of Representatives (DPRD) itself. For sure this fact is so shameful and decrease the credibility of Regional House of Representatives (DPRD) itself and become a warning for local government. Various case that happened in Indonesia, particularly in North Borneo Province, both in regency and city level showed that criminal act of corruption tend to did by individual in Regional House of Representatives (DPRD) itself. 
All about Regional House of Representatives (DPRD) recently have indicated that credibility of Regional House of Representatives (DPRD) member as honourable institution which have monitoring function start to be doubted, even there are some people that become very antipathy because people going untrust to Regional House of Representatives (DPRD).

As example, corruption case of operational fund of Kukar Regional House of Representatives (DPRD) in 2005-2006 be discovered drag 37 defendants which the defendants are the member of Regional House of Representatives (DPRD) period 2004-2009, among of them are 14 exmember of Regional House of Representatives (DPRD) period 2004-2009, 15 non-active member of Regional House of Representatives (DPRD) period 2009-2014, and a number of East Borneo's Regional House of Representatives (DPRD) (ex-member of Kukar's Regional House of Representatives (DPRD) period 2004-2009). 14 defendants, ex-member of Kukar's Regional House of Representatives (DPRD) are prosecuted in Regency Court of Tenggarong. 15 non-active member and a few persons East Borneo Province's Regional House of Representatives (DPRD) are prosecuted in Tipikor Court of Samarinda. As well as what happened in Kutai Timur Regency, there is a member of Regional House of Representatives (DPRD) who had been selected for three period, allegedly had cut his council aspiration fund in 2008 amount 340 million rupiahs. This fund should gave to Harapan Jaya Mandiri farmer's group amount of 300 million rupiahs and Banten Lestari farmer's group amount of 200 million rupiahs.

Thereby, this problem must becoming serious attention for state institutions, both executive or legislative and all elements of society, no 
exception for Regional House of Representatives (DPRD) in Bulungan Regency to participate on reporting events that occur in their area, so that deviation toward Regional House of Representatives (DPRD) could be minimized, also implementation of regional budget (APBD) suitable with Act's mandate.

\section{LITERATURE REVIEW}

Karim, Aulia Sobri (2011) under the title "Implementation of the Function of Supervision of Parliament of Salatiga City towards Salatiga Mayor's Policy of 2010.

The result of his research is in the implementation of the oversight function of the City Council of Salatiga always strives to maintain the administration by the Mayor of Salatiga. The form of supervision made by Parliament of Salatiga City is more towards prevention, but sometimes does not close the possibility of its supervision can also be repressive (correcting). The mechanism or steps taken by the City Council of Salatiga in conducting supervision, through the evaluation of the policies taken by the Mayor of Salatiga, with direct findings that are considered to cause problems for the community or through complaints from the community.

\section{RESEARCH METHOD}

The type of this research is descriptive qualitative research, that aimed to give a picture of situation systematically, factually, and accurately about the object of the research, which 
the result of descriptive will be continued with detail explanation.

This research will conducted in Regional House of Representatives (DPRD) Bulungan Regency, Tanjung Selor, located in Nuri Street, Number 56, Tanjung Selor, North Borneo.

Technique of data collection in qualitative research could be conducted through collection of moving data from empiric fact in order to build theory. Process of this data collection is explained by Nasution (1998: 34) encompass some steps below.

\section{RESULT AND DISCUSSION}

\section{A. RESULT}

1. Monitoring Function of Regional House of Representatives (DPRD) Bulungan regency toward implementation of regional regulation about regional budget (APBD) in 2015

In Act number 23 year of 2014, the position of Regional House of Representatives (DPRD) placed on the very strategic position and decisive within implementation of regional autonomy on local government implementation and placed as element of local government implementation that have functions of legislation, budget, and monitoring.

Monitoring function of regional regulation is very important which give opportunity toward Regional House of 
Representatives (DPRD) to respond various obstacles more actively and creatively toward implementation of regional regulation.

Throughout assembly monitoring, executive as the implementator of policy will be spared from various kinds of deviation and misappropriation, from the result of assembly monitoring will be taken perfection act to improve implementation of that policy. In order to avoid various administrative errors on governance of local government bureaucracy unwittingly could disembogue on presumption of criminal act of corruption for public officials who handle that public affairs. Monitoring by Regional House of Representatives (DPRD) would give protection which effective enough toward executive on the running the goverment of government bureaucracy optimally.

Total of regional budget of Bulungan regency in 2015 amount of Rp. 2.774.762.424,237,61,. (Two trillion seven hundred seventy four billion seven hundred sixty two million four hundred twenty four thousand two hundred thirty seven rupiah sixty one cent) with realization before audit amount of $\mathrm{Rp}$.

1.917.474.198.999,24,. That matters suitable with Regional House of Representatives (DPRD) Bulungan regency's decision number 3 year of 2014 about approval toward draft of Bulungan regency's regional regulation draft about regional budget (APBD) of Bulungan regency, year budget of 2014. Under the details of expenditure in the following table below:

Table 3. Expenditure Details of Local Government of Bulungan Regency in budget year of 2014 


\begin{tabular}{|c|c|c|c|}
\hline No & $\begin{array}{l}\text { Expenditure } \\
\text { Description }\end{array}$ & Budget (Rp) & Realization (Rp) \\
\hline \multirow[t]{4}{*}{1} & $\begin{array}{l}\text { Direct } \\
\text { Expenditure }\end{array}$ & $\begin{array}{l}1.783 .330 .931 \\
498,32\end{array}$ & $\begin{array}{l}1.211 .433 .141 .981, \\
47\end{array}$ \\
\hline & $\begin{array}{l}\text { A. Employee } \\
\text { expenditure }\end{array}$ & $\begin{array}{r}74.809 .767 .238 \\
, 00\end{array}$ & 55.011 .251 .550 .00 \\
\hline & $\begin{array}{l}\text { B. Goods and } \\
\text { Service } \\
\text { Expenditur } \\
\mathrm{e}\end{array}$ & $\begin{array}{r}497.164 .306 .34 \\
3,00\end{array}$ & $363.303 .259 .042,10$ \\
\hline & $\begin{array}{l}\text { C. Capital } \\
\text { expenditure }\end{array}$ & $\begin{array}{r}1.211 .356 .857 \\
917,32\end{array}$ & 793.118 .631 .389 .37 \\
\hline \multirow[t]{7}{*}{2} & $\begin{array}{l}\text { Indirect } \\
\text { Expenditure }\end{array}$ & $\begin{array}{l}991.431 .492 .73 \\
9,29 .\end{array}$ & $\begin{array}{l}706.041 .057 .017,7 \\
7\end{array}$ \\
\hline & $\begin{array}{l}\text { A. Employee } \\
\text { expenditure }\end{array}$ & $\begin{array}{r}641.161 .704 .73 \\
9,29 \\
\end{array}$ & $399.739 .315 .020,00$ \\
\hline & $\begin{array}{l}\text { B. Grant } \\
\text { expenditure }\end{array}$ & $\begin{array}{r}290.213 .890 .00 \\
0,00\end{array}$ & $256.961 .722 .500,00$ \\
\hline & $\begin{array}{l}\text { C. Social } \\
\text { Assistance } \\
\text { expenditure }\end{array}$ & $\begin{array}{r}4.524 .680 .000 \\
00\end{array}$ & $4.429 .680 .000,00$ \\
\hline & $\begin{array}{l}\text { D. Profit } \\
\text { Sharing } \\
\text { expenditure }\end{array}$ & $\begin{array}{r}45.531 .218 .000 \\
, 00\end{array}$ & $44.910 .339 .497,27$ \\
\hline & $\begin{array}{ll}\text { E. Sudden } \\
\text { expenditure }\end{array}$ & $\begin{array}{r}10.000 .000 .000 \\
, 00\end{array}$ & 0,00 \\
\hline & Jumlah & $\begin{array}{r}2.774 .762 .424 \\
237,61 \\
\end{array}$ & $\begin{array}{r}1.917 .474 .198 .999, \\
24\end{array}$ \\
\hline
\end{tabular}

Beside that, there are some components of regional financing that consist of regional income and regional expenditure with details below:

a. Regional income which budgeted for Rp. 
1.506.671.903.335,81, with realization before audit amount of 1.506.671.903.335,81.

b. Regional expenditure which budgeted for Rp. 20.000.000.000,- with realization before audit amount of Rp.20.000.000.000,-

In the matter of not yet optimal of budget absorption in local government or regional work unit (SKPD) of Bulungan regency show that budget implementation not yet a performancebased budget. It can be known from the still lack of budget absorption in grants expenditure because the process and procedure still not yet be understood by some people and still many of regional work unit (SKPD) that propose revision of DPA both the budget and the activity planning, this fact reflects the absence of a mature activity planning program.

\section{B. DISCUSSION}

1. Monitoring Function of Regional House of Representatives (DPRD) Bulungan regency toward implementation of regional regulation about regional budget (APBD) in 2015

The form of monitoring which did by Regional House of Representatives (DPRD) is a political monitoring, i.e monitoring that conducted by legislative institution or DPRD toward executive institution (Head of region, vice head of region along with the region staff) that more of a strategic policy and not a technical or administrative oversight, because Regional House of 
Representatives (DPRD) is a political institution so budget utilization which had allocate, misused for things that harm the people and the state.

In Act number 23 year of 2014, the position of Regional House of Representatives (DPRD) placed on the very strategic position and decisive within implementation of regional autonomy on local government implementation and placed as element of local government implementation that have functions of legislation, budget, and monitoring.

Monitoring function of regional regulation is very important which give opportunity toward Regional House of Representatives (DPRD) to respond various obstacles more actively and creatively toward implementation of regional regulation. Throughout assembly monitoring, executive as the implementator of policy will be spared from various kinds of deviation and misappropriation, from the result of assembly monitoring will be taken perfection act to improve implementation of that policy. In order to avoid various administrative errors on governance of local government bureaucracy unwittingly could disembogue on presumption of criminal act of corruption for public officials who handle that public affairs. Monitoring by Regional House of Representatives (DPRD) would give protection which effective enough toward executive on the running the goverment of government bureaucracy optimally.

The scope of monitoring which did by Regional House of Representatives (DPRD) covers all the regional work unit (SKPD) 
and programs or policy which is financed by regional budget (APBD), because one of local government aspect that needs to be set carefully is management of regional finance because it plays important role on supporting the cycle of government implementation in region to create welfare for the people. A regional budget (APBD) in a region is a regional breath to continue local development. Local development could be ran if monitoring toward regional budget (APBD) execution goes well suitable with the priority and aspiration from the people.

Budget for local government is a very important instrument on economic policy which more explain the policy priority of others documents, in another words, budget define policy, political commitments and priority in decide where the budget must be used and where that must be collected.

2. Monitoring of Regional House of Representatives (DPRD) toward Accountability Description Report of Region Head in 2014

Based on the provision in the clause 184 Act number 32 year of 2004 , told:

1) Head of region submit the draft of regional regulation about implementation accountability of regional budget (APBD) toward Regional House of Representatives (DPRD) be in the form of financial report which was checked by Finance Audit Board (BPK) at the latest six months after budget year end.

2) Financial report at least covers realization report of regional budget (APBD), scale, cash flow report, and notes to financial report, that 
attached with financial report of regional owned enterprises (BUMD).

3) Financial report is arranged and presented suitable with the standard of government accounting which is set with government regulation $(\mathrm{PP})$.

Generally, management of each structures of regional budget (APBD) of 2006 that get monitoring from Regional House of Representatives (DPRD) as follows:

1) Management of income

Based on the visible illustration on LKPJ Bulungan Regent in 2014, realization receipt of locally-generated revenue (PAD) increase or more than the target that had been set. The increasing of PAD, according to author, it can be apart from the hardwork of local revenue management apparatus, doing intensification toward every revenue sources like tax, retribution, or another revenues throughout service improvement toward retribution-tax payer both directly when make a payment or increase through socialization counseling. Implement the monitoring strictly neither from the internmonitoring nor monitoring which is conducted by Regional House of Representatives (DPRD) toward regional revenue sources so that expected there is no leakage in its implementation, including people awareness on carry out their responsibility. Also increase the coordination with agency/institution that related with the effort to maximize 
regional revenue income which had been set in regioal budget (APBD).

In generally, it can be said that either from regional apparatus expenditure nor public service expenditure, the realization is smaller than which had been planned. Economically, this phenomenon give positive indicative (there is efficiency or savings on regional expenditure management, this budget savings become residue of UUDP and budget remains. It is used to defray General Administration Expenditure (BAU), operational and maintenance expenditure, and capital expenditure.

According to the research of author all this time, there has been no description report of accountability of Bulungan Regent which was rejected, those reports could be accepted with the provision of fulfill the weaknesses that contained in report suitable with recommendation which given by Regional House of Representatives (DPRD). This is a politic for Regional House of Representatives (DPRD)'s member to understand each other about the future election, in order to get support from executive in eventually election.

B. The Obstacles on Implementation of monitoring function of Regional House of Representatives (DPRD) Bulungan Regency about regional budget (APBD) Bulungan Regency in 2015

In running its duty, i.e monitoring toward management of regional budget (APBD), Regional House of Representatives 
(DPRD)'s Bulungan Regency have some obstacles, such as:

a. Internal Factor

1. The lack of disciplines from Regional House of Representatives (DPRD)'s member of Bulungan regency within obey the rules and ethic code of Regional House of Representatives (DPRD) of Bulungan regency. So, there is no strong internal base from Regional House of Representatives (DPRD) of Bulungan regency to implement monitoring function through good prestige and image amid of people who their represented.

2. The level of expertness of Regional House of Representatives (DPRD)'s member of Bulungan regency in certain fields which become monitoring object is anadequate. This is motivated by the education of Regional House of Representatives (DPRD)'s member of Bulungan regency that not expert in Constitutional Law and inadequate of their experience on governance.

3. Inadequate of organization experience that have owned by the member, in particular in the administration field of government bureaucracy, so in the conduct the evaluation and recapitulation of regional budget (APBD) utilization which proposed by the regent in approaching the end of budget year still not smart and careful.

4. Human resource and the occupation background of Regional House of Representatives (DPRD)'s member of 
Bulungan Regency that are diverse because they come from political party, not a government expert and law expert. Regional House of Representatives (DPRD)'s member of Bulungan Regency have diverse background, that mostly do not understand the complication of government would tribulate legislative side within implement monitoring function because, to run the maximum monitoring function needs good understanding about the object of monitoring.

5. Domination of political party interest from each fraction causes non-fluent communication between one fraction and the other fraction. In this matter, more to the political interest each fraction. Fraction is a party's "extension of the hand" that exist on Regional House of Representatives (DPRD), have each interest, so in the decide a policy including monitoring seldom different between one fraction to another fraction.

6. The knowledge of Regional House of Representatives (DPRD)'s member of Bulungan Regency about monitoring functional limits that become their authority. Monitoring which is conducted by Regional House of Representatives (DPRD)'s member toward executive institution, is a set of monitoring activities like monitor, examination, evaluation toward public policy implementation that suitable with rules that had been set. 
But, not every member of Regional House of Representatives (DPRD) of Bulungan Regency understand the limits of monitoring scope and the monitoring characteristic of Regional House of Representatives (DPRD).

b. External Factor

1. Monitoring toward strategic and vital project are more political. It causes deviations if it happened protracted. Because in monitoring, Regional House of Representatives (DPRD) is wait so long the statement from project leader or project implementator. In addition, there is an indication that Regional House of Representatives (DPRD) scared losing political support more rational in the election, both in the form of finance or vote. Certainly, the implementators of vital and strategic project have established finance.

2. The lack of complementary data. It is difficult to get complete datas to support implementation of monitoring function. Because, Regional House of Representatives (DPRD) of Bulungan regency itself not all have a good relationship with the government as well as all elements of society. So, the lack of complementary data could obstruct the monitoring implementation of Regional House of Representatives (DPRD).

3. The time of discussion with the entry time of regional 
regulation draft of regional budget, is too short. Regional regulation draft of regional budget which enter to Regional House of Representatives (DPRD) with the discussion schedule is too short, so the time to read, understand, evaluate, asses the regional regulation draft before it being discussed, is very lack and it is not supported by human resource which adequate from the member in the field of finance. So, the matter is how to discuss the regional regulation draft as soon as possible, and the budget could be used immediately.

4. There is no monitoring network that adequate and weak law enforcement. Law enforcement contribute to effectivity of monitoring function of Regional House of Representatives (DPRD). During on law enforcement still could not be dependable, monitoring function of Regional House of Representatives (DPRD) also could not optimally implemented. This condition show that it is needed a network of monitoring collaboration between Regional House of Representatives (DPRD) of Bulungan regency with the justice institution and others institution. The monitoring function of Regional House of Representatives (DPRD) in arrange the regional expenditure budget, there is still difference in the way to decide priority scale and regional budget (APBD) program that had been set by local government with the commissions in Regional House of 
Representatives (DPRD).

5. The member of Regional House of Representatives (DPRD) of Bulungan regency are not given adequate basic reference about policy and base rule framework which is frame its policy implementation.

\section{CONCLUSION}

Based on the previous description, neither from the result of research nor on the problem focus discussion, so could be concluded that:

1. Monitoring function toward regional regulation implementation about regional budget (APBD) in Bulungan regency on the running monitoring function toward regional budget (APBD) implementation in 2015 had been running, but not yet optimal. This is evidenced by still being encountered of unsynchronize between planning with the result of musrenbang which has been set and become the development priority. This is showed political commitment of Regional House of Representatives (DPRD) still not yet optimal toward budget monitoring.

2. Regional House of Representatives (DPRD) of Bulungan regency within implement monitoring toward regional regulation implementation about regional budget (APBD) in 2015 faces some obstacles, there are some difference about understanding and scope of monitoring among Regional House of Representatives (DPRD)'s member on interprete monitoring 
function because regulation that adjust about monitoring points that must be implemented by Regional House of Representatives (DPRD not yet exist.

3. The knowledge of Regional House of Representatives (DPRD)'s member of Bulungan Regency about monitoring functional limits that become their authority. Monitoring which is conducted by Regional House of Representatives (DPRD)'s member toward executive institution, is a set of monitoring activities like monitor, examination, evaluation toward public policy implementation that suitable with rules that had been set. But, not every member of Regional House of Representatives (DPRD) of Bulungan Regency understand the limits of monitoring scope and the monitoring characteristic of Regional House of Representatives (DPRD).

4. Related with the achievement of Regional House of Representatives (DPRD) in Bulungan regency within implement the monitoring function that related with regional regulation about regional budget (APBD) in 2014 only normative, there is nothing extraordinary or very significant findings. The member of Regional House of Representatives (DPRD) tend do not understand and knowing both contextually or contently about monitoring function itse

5. Even if there is a findings within arrangement of RAPBD that is incompatibility between program which had been planned with the program which had been purposed in musrenbang, the act that did by Regional House of Representatives (DPRD) only corrective, there is no sanction or punishment for local government in this case is regent. 


\section{REFERENCES}

Al-Amin, Mufham. (2006). Manajemen Pengawasan . Jakarta: Kalam Indonesia

Arikunto, Suharsimi. (2006). Prosedur penelitian Suatu pendekatan praktek. Jakarta : Rineka Cipta

Aziz Syamsudin. (2011). Proses dan Teknik Perundang-Undangan, Jakart: Sinar Garfika, hlm 13.

Bagir Manan dalam W. Riawan Tjandra dan Kresno Budi Harsono. (2009). Legislatif Drafting Teori dan Teknik Pembuatan Peraturan Daerah, Yogyakarta: Universitas Atmajaya.

Budiman NPD. (2005). IImu Pengantar Perundang-Undnagan UII press Yogyakarta, hlm 33.

Fachruddin, Irfan. (2004). Pengawasan Peradilan Administrasi Terhadap Tindakan Pemerintah. Bandung : PT. Alumni Bandung.

Kaelan. (2005). Metode Penlitian Kualitatif Bidang Filsafat. Yogyakarta: Paradigma

Kunarjo. (2002). Perencanaan dan Pengendalian Program Pembangunan, Universitas Indonesia UI Press, Jakarta.

Milles, Matthew B dan A M ichael Huberman. (2007). Analisis Data Kualitatif. Jakarta: UI-Press.

Moleong, Lexy. (2001) Metodologi Penelitian Kualitatif , PT. Remaja Rosada Karya, Bandung.

Rahardjo Adisasmita. (2011). Pengelolaan Pendapatan \& Anggaran Daerah. Penerbit Graha Ilmu : Yogyakarta.

Singarimbun, M asri dan sofyan Effendi. (1986). Metode Penelitian Survey, Suntingan LP3ES, Jakarta.

Sugiyono. (2009). Memahami Penelitian Kualitatif, Alfabet. Jakarta.

Undang-Undang No. 22 Tahun 1999 tentang Pemerintah Daerah

Undang-Undang No. 25 Tahun 1999 tentang Pemerintah Daerah

Undang-Undang No. 32 Tahun 2004 tentang Pemerintah Daerah

Undang - Undang Nomor 23 Tahun 2014 tentang Pemerintahan Daerah

Undang-Undang No. 33 Tahun 2004 Perimbangan Keuangan antara Pusat dan Daerah 
H. Undang-Undang No. 15 Tahun 2004 tentang Pemeriksaan pengelolaan dan Tanggung jawab Keuangan Negara

Topatimasang, Roem; Mansour Fakih dan Toto Rahardjo. (2007). Mengubah Kebijakan Publik. INSISTPress. Yogyakarta. 